\title{
THE IMPORTANCE OF CREDITS FOR AGRICULTURE IN GENERATING NET PROFIT OF COOPERATIVE BANKS IN 2015-2017
}

\author{
Sławomir Juszczyk, Full Professor'; Rafał Balina, PhD²; \\ Piotr Chrzanowski, $\mathrm{MSc}^{3}$
}

1, 2, 3 Faculty of Economic Sciences, Warsaw University of Life Sciences - SGGW

${ }^{3}$ Warsaw Cooperative Bank

\begin{abstract}
The aim of the research was to determine whether and to what extent credits for agriculture, that is credits granted to individual farmers and preferential credit for agriculture, affected the level of net profit of cooperative banks in Poland in 2015-2017. Among others, it was established that credits granted to individual farmers are important for generating net profit for both small, medium and large cooperative banks. However, the values of the regression coefficient for this variable were low, with a slight increasing tendency. The variable, however, defining preferential credits for agriculture appeared only in two out of nine models constructed and with a negative sign. This concerned small and medium-sized cooperative banks. For large cooperative banks, preferential credit for agriculture were not of key importance in generating net profit. One can conclude that preferential credit does not bring financial benefits to cooperative banks. It is necessary to make financial revenues reliable, taking into account the costs of servicing preferential credits.
\end{abstract}

Keywords: credits granted to individual farmers, preferential credits for agriculture, net profit, cooperative banks

JEL codes: G210, G290

\section{INTRODUCTION}

The development of agriculture and the food economy as well as small and medium-sized enterprises, especially in rural areas, is influenced by cooperative banks, which are Polish in terms of capital and ownership. They are located evenly throughout the country and specialize in servicing agriculture, small and medium enterprises, local self-governments as well as the rural and urban population. There are also coopera- tive banks in provincial cities and even in the capital, however, these are clearly banks which are larger than other cooperative banks and usually serve suburban fruit and vegetable producers as well as workshops.

It is worth noting that cooperative banks in Poland have been operating for over 150 years and are mainly associated with rural areas and small towns. Compared to commercial banks, they are smaller, but generally more strongly rooted in the local environment, which they support in different ways.

${ }^{1}$ Corresponding author: Nowoursynowska 166, 02-787 Warsaw, Poland, slawomir_juszczyk@sggw.pl, +4822 5934241

${ }^{2}$ Corresponding author: Nowoursynowska 166,02-787 Warsaw, Poland, rafal_balina@sggw.pl, +4822 5934270

${ }^{3}$ Corresponding author: Nowoursynowska 166,02-787 Warsaw, Poland, piotr_chrzanowski@op.pl, +4822 5148940 


\section{THEORETICAL BACKGROUND, MATERIALS AND METHODS}

The purpose of the conducted research was to determine whether and to what extent credits for farms and preferential credits for these farms affect the level of net profit of cooperative banks in Poland and determine the answer to the question whether the importance of these credits in 2015, 2016 and 2017 increased or decreased. The implementation of the research objective required literature studies and empirical research.

One of the important problems in economic research is the selection of the sample. It is possible to include all objects in the study, that is comprehensive research, as well as the selection of only certain population units (Klepacki, 1984). Initially, the research was intended to cover all cooperative banks operating in Poland as of 31 December 2017, i.e. 553 banks. However, during the research period, 91 banks were subject to merger processes or significant organizational changes, which is why they were omitted. The remaining 462 banks, i.e. $83.5 \%$, were ranked in ascending order of total assets and were drawn, every fourth bank starting from a bank ranked second. The research, therefore, covered 115 banks, i.e. nearly $20.8 \%$ of the total, as of the end of 2017 . The source material was:

- statistical data of the Polish Financial Supervision Authority,

- statistical data of the Bank Guarantee Fund,

- statistical data of associating banks,

- publications of the National Bank of Poland,

- mass statistics data on the European Union and Poland,

- statistical data of individual cooperative banks.

The key measure of an entity's growth and assessment of financial effectiveness constitutes the net profit. amount One can even say that this is the most important measure. Szustak believes that achieved profit results in an increase in market value, the payment of dividends to owners, an increase in bank credibility on the market and also determines the degree of self-financing of a bank's development. What is more, net profit is also an important source of financing of own funds (Szustak, 2009). Analysis was carried out within separate groups of banks according to own funds (Różyński, 2014). Group 1 constituted the smallest banks, characterized by the lowest level of own funds, i.e. up to PLN 5 million. Group II included medium-sized banks with own funds of over PLN 5 million to 15 million. The last group, the third one, consisted of the largest banks, i.e. with a level of own funds over PLN 15 million. These groups were homoscedastic.

In the next stage of the research, an estimation of regression models explaining the level of net profit in the above mentioned groups of cooperative banks was made separately for the years 2015, 2016 and 2017. In total, 9 econometric models were constructed. Research in this area conducted according to the following scheme (Welfe, 2003):

1. Preparation of model specification:

- determination of the purpose and scope of the dependent variable study,

- determination of potential independent variables,

- initial reduction of potential independent variables,

- construction of the analytical form of the model.

2. Estimation of the structural parameters of the model.

3. Statistical verification of the constructed model, during which the following was assessed:

- the level of the determination coefficient,

- the normality of the residual component distribution using the Jarque-Bera compliance test,

- the heteroscedasticity of distribution using White test (Ramanathan, 1995); after calculating the White statistic, it was compared to the critical value Chi-square test $\left(\chi^{2}\right)$ to determine significance level $\alpha$ and $p$ degrees of freedom,

- the collinearity of explanatory variables using the inflation factor VIF - variance inflation factors (Madala, 2006), which was determined according to the equation:

$$
V I F_{j}=\frac{1}{1-R_{j}^{2}}
$$

where:

$R_{j}^{2}$ - the coefficient of multiple correlation between variable $x_{j}$ and other variables. 
If the value of $V I F_{j}$ was equal to 1 , it meant that the analysed variable was uncorrelated with the remaining explanatory variables (Gruszczyński and Podgórska, 2000).

\section{RESULTS AND DISCUSSION}

\section{Small cooperative banks (group I)}

Using the scheme of selecting indicators for the model, potential variables that could influence net profit generated by cooperative banks in 2015 were determined. In the first step, a correlation matrix was determined between the explained variable and nineteen potential explanatory variables considered in the study and between all explanatory variables.

Taking into account the adopted critical value of the correlation coefficient, explanatory variables strongly correlated with each other were eliminated until the set of explanatory variables strongly correlated with the explained variable and weakly correlated with each other (Dziechciarz, 2003). The analysis of correlation coefficients between the analysed variables, taking into account the above assumptions, showed that in 2015-2017 there were 13 variables which were significant and fulfilling:

$-X_{3}$ - share fund (PLN thous.),

- $X_{4}$ - resource fund (PLN thous.),

$-X_{5}$ - reserve fund (PLN thous.),

$-X_{6}-$ general risk fund (PLN thous.),

- $X_{7}$ - supplementary fund (PLN thous.),

- $X_{12}$ - credits granted to enterprises and private companies (PLN thous.),

- $X_{13}$ - credits granted to individual entrepreneurs (PLN thous.),

- $X_{16}$ - credits granted to non-commercial institutions operating for the benefit of households (PLN thous.),

- $X_{15}$ - credits granted to individual farmers (PLN thous.),

- $X_{16}$ - credits granted to non-profit institutions conducting activities for the benefit of households (PLN thous.),

- $X_{17}$ - preferential credits for agriculture (PLN thous.),

- $X_{18}$ - number of people employed in the bank (pcs.),
- $X_{19}$ - net assets (PLN thous.).

After determining key variables explaining the net profit of cooperative banks with own funds below PLN 5 million, parameters of the regression function were estimated. The final net profit models for small banks are as follows:

a) for 2015

$Z N_{\mathrm{I} 2015}=273.694+0.15446 X_{4}-0.00346682 X_{17}$

where:

$Z N_{\text {I } 2015}$ - net profit of the bank from group I, in 2015 (PLN thous.),

$X_{4}$ - resource fund (PLN thous.),

$X_{17}$ - preferential credits for agriculture (PLN thous.).

Among the variables significant for the level of net profit obtained by banks with funds below PLN 5 million, in 2015, there were two explanatory variables, one variable positively affecting the net profit of cooperative banks. This variable was a resource fund, which increased by PLN 100 thousand, increasing net profit by PLN 15.44 thousand. Interestingly, preferential credits for agriculture had a negative impact on the level of net profit, as their increase by PLN 100 thousand resulted in a drop of net profit on average by nearly PLN 350 .

b) for 2016

$$
\begin{aligned}
Z N_{\text {I } 2016}= & 233.51+0.187878 X_{4}+0.00214498 X_{15}+ \\
& +0.009559886 X_{19}
\end{aligned}
$$

where:

$Z N_{\text {I } 2016}$ - net profit of the bank from group I, in 2016 (PLN thous.),

$X_{4}$ - resource fund (PLN thous.),

$X_{15}$ - credits granted to individual farmers (PLN thous.),

$X_{19}-$ net assets (PLN thous.).

In the case of the $Z N_{I 2016}$ model, three variables were of key importance, the increase of which positively influenced net profit level. The first variable was the level of the resource fund, which increase by PLN 100 thousand, increasing net profit by PLN 
18.8 thousand. The second variable was the sum of credits granted to individual farmers, whose increase by PLN 100 thousand increased net profit by PLN 0.21 thousand. The third variable was the net asset value, whereby an increase of PLN 100 thousand increased the cooperative bank's profit from this group in 2016 by PLN 0.95 thousand.

c) for 2017

$$
\begin{aligned}
Z N_{\text {I } 2017}= & 2,363.556+0.188221 X_{4}+0.0112136 X_{10}+ \\
& +0.0953343 X_{16}
\end{aligned}
$$

where:

$Z N_{\mathrm{I} 2017}$ - net profit of the bank from group I, in 2017 (PLN thous.),

$X_{4}$ - resource fund (PLN thous.),

$X_{10}$ - total bank credit exposure (PLN thous.),

$X_{16}$ - credits granted to non-commercial institutions operating for the benefit of households (PLN thous.).

The estimated $Z N_{\mathrm{I} 2017}$ regression function for small cooperative banks shows that both credits granted to individual farmers and preferential credits were not decisive factors for the net profit level of these banks in 2017.

\section{Medium cooperative banks (group II)}

Using the adopted scheme of conduct, in order to determine the function explaining the cooperative bank's net profit with own funds of more than PLN 5 million to 15 million, for the years 2015-2017, 10 following variables were defined that met the assumptions concerning the value of correlation coefficients, i.e.:

$-X_{3}$ - share fund (PLN thous.),

- $X_{4}$ - resource fund (PLN thous.),

$-X_{5}-$ reserve fund (PLN thous.),

- $X_{6}-$ general risk fund (PLN thous.),

$-X_{7}$ - supplementary fund (PLN thous.),

- $X_{14}$ - credits granted to individuals (PLN thous.),

- $X_{15}$ - credits granted to individual farmers (PLN thous.),

- $X_{16}$ - credits granted to non-commercial institutions operating for the benefit of households (PLN thous.),
- $X_{17}$ - preferential credits for agriculture (PLN thous.),

- $X_{18}$ - number of people employed in the bank (pcs.).

These variables were used to estimate the regression model explaining the level of net profit for entities from the analysed group. The final net profit models for medium-sized cooperative banks are as follows:

a) for 2015

$Z N_{\text {II } 2015}=97.8303+0.14332 X_{4}+0.00659062 X_{15}$

where:

$Z N_{\text {II } 2015}$ - net profit of the bank from group II, in 2015 (PLN thous.),

$X_{4}$ - resource fund (PLN thous.),

$X_{15}$ - credits granted to individual farmers (PLN thous.).

In the regression model of net profit for cooperative banks with own funds of more than PLN 5 to 15 million, for 2015, there were two variables - for the resource fund and credits granted to individual farmers. They were stimulants, because they increased by PLN 100 thousand resulting in an increase in net profit respectively by PLN 14.33 thousand and nearly PLN 0.66 thousand.

b) for 2016

$$
\begin{aligned}
Z N_{\text {II } 2016}= & 43.3678+0.14966 X_{4}+0,144729 X_{6}+ \\
& +0.0289991 X_{15}
\end{aligned}
$$

where:

$Z N_{\text {II } 2016}$ - net profit of the bank from group II, in 2016 (PLN thous.),

$X_{4}$ - resource fund (PLN thous.),

$X_{6}-$ general risk fund (PLN thous.),

$X_{15}$ - credits granted to individual farmers (PLN thous.).

The analysis shows that in cooperative banks with own funds over PLN 5 to 15 million, in 2016, a significant but slight increase in net profit was generated by the change in the level of credits granted to individual farmers, whereby an increase of PLN 
100 thousand was connected with an increase of net profit of nearly PLN 2.9 thousand.

c) for 2017

$$
\begin{aligned}
Z N_{\text {II } 2017}= & 69.1455+0.015924 X_{3}+0.118814 X_{4}+ \\
& +0.153184 X_{6}+0.017412 X_{14}- \\
& -0.00806114 X_{17}
\end{aligned}
$$

where:

$Z N_{\text {II } 2017}-$ net profit of the bank from group II, in 2017 (PLN thous.),

$X_{3}$ - share fund (PLN thous.),

$X_{4}$ - resource fund (PLN thous.)

$X_{6}-$ general risk fund (PLN thous.),

$X_{14}$ - credits granted to individuals (PLN thous.),

$X_{17}-$ preferential credits for agriculture (PLN thous.).

There are five explanatory variables in the $Z N_{\text {II }}$ 2017 model. Three of them pertained to the level of own funds of cooperative banks and the other two - credits. However, the increase in preferential credits for agriculture of PLN 100 thousand resulted in a net profit decrease by PLN 806 on average.

In 2015 and 2016, the level of net profit of medium-sized cooperative banks was significantly and positively affected by credits granted to individual farmers. Moreover, in 2016, the importance of these credits was higher than in 2015. Preferential credits for agriculture, reduced the profit of this group of banks in 2017. Furthermore, they were granted due to social reasons and should therefore be assessed positively. However, this situation requires a change and realignment of costs related to servicing these credits.

\section{Large cooperative banks (group III)}

In the course of the conducted research, a correlation matrix between the analysed variables was determined for banks with own funds over PLN 15 million. The analogous procedure was used as before and 5 variables, which best described the volatility of net profit in the studied group were determined. These variables are:

- $X_{3}$ - share fund (PLN thous.),

- $X_{4}$ - resource fund (PLN thous.),

$-X_{6}-$ general risk fund (PLN thous.),

- $X_{14}$ - credits granted to individuals (PLN thous.),
$-X_{15}-$ credits granted to individual farmers (PLN thous.).

The final net profit models for large cooperative banks are as follows:

a) for 2015

$$
\begin{aligned}
Z N_{\text {III } 2015}= & 1,745.26+0.001234 X_{3}+0.146833 X_{4}+ \\
& +0.0280734 X_{14}+0.0116223 X_{15}
\end{aligned}
$$

where:

$Z N_{\text {III } 2015}$ - net profit of the bank from group III, in 2015 (PLN thous.),

$X_{3}$ - share fund (PLN thous.),

$X_{4}$ - resource fund (PLN thous.),

$X_{15}$ - credits granted to individual farmers (PLN thous.).

b) for 2016

$$
\begin{aligned}
Z N_{\text {III } 2016}= & 46.2223+0.0097695 X_{3}+0.150422 X_{4}+ \\
& +0.304948 X_{6}
\end{aligned}
$$

where:

$Z N_{\text {III } 2016}$ - net profit of the bank from group III, in 2016 (PLN thous.),

$X_{3}$ - share fund (PLN thous.),

$X_{4}-$ resource fund (PLN thous.),

$X_{6}-$ general risk fund (PLN thous.).

c) for 2017

$$
\begin{aligned}
Z N_{\text {III } 2017}= & 1,540.15+0.0732446 X_{3}+0.1714456 X_{4}+ \\
& +0.0776673 X_{6}+0.0144878 X_{15}
\end{aligned}
$$

where:

$Z N_{\text {III } 2017}$ - net profit of the bank from group III, in 2017 (PLN thous.),

$X_{3}$ - share fund (PLN thous.),

$X_{4}-$ resource fund (PLN thous.)

$X_{6}-$ general risk fund (PLN thous.).

$X_{15}$ - credits granted to individual farmers (PLN thous.).

For large cooperative banks, the importance of preferential credits for agriculture in 2015-2017 was not a decisive factor in shaping net profit. In 2015 and 2017 credits granted to individual farmers were significant for large cooperative banks. It is also worth noting that the significance of these credits in 2017 
was higher than in 2015. Statistical calculations indicate that credits granted to individual farmers even by large cooperative banks, often having their headquarters in cities, is still an important factor positively affecting the increase of net profit.

The coefficient of determination of individual models was between 0.76020 for the small bank model for 2015 and 0.92698 for the medium bank model for 2016. This means that models constructed for a group of cooperative banks explained the volatility of net profit, over $76 \%$, which was considered to be a satisfactory level.

\section{CONCLUSIONS}

The conducted research showed that, in the years 2015-2017, the number of variables changed, which, due to statistical reasons, had a key impact on the level of net profit of cooperative banks in Poland. In the net profit models for large cooperative banks in the individual study years, the number of variables was the smallest. This may indirectly indicate that the management of large cooperative banks may be organizationally easier than smaller ones.

The variable $X_{15}$ defining the level of credits granted to individual farmers was included in 5 models out of 9 constructed. What is more, this variable was important for generating net profit for both small, medium and large cooperative banks. However, it should be emphasized that the values of the regression coefficient for this variable were relatively low, but with a tendency to slightly increase.

A separate issue is preferential credits for agriculture. In 9 models explaining the level of generated net profit of cooperative banks, the variable $X_{17}$, relating to these credits, only appeared twice with a negative sign. This concerned small and medium-sized cooperative banks. For large cooperative banks, preferential credits for agriculture are not a key factor in generating net profit. Therefore, it can be concluded that these credits do not bring financial benefits to cooperative banks and may even be associated with the situation that costs may be higher than financial benefits achieved. Nevertheless, what deserves recognition is the fact that cooperative banks, especially small and medium-sized banks, service these credits because of their missionary and subsidiarity towards members and the entire environment related to the development of agriculture and rural areas. Regardless of this, it is necessary to make the financial revenues resulting from the costs of servicing these credits real.

\section{REFERENCES}

1. Dziechciarz, J. (2003). Ekonometria. Metody, przykłady, zadania [Econometrics. Methods, examples, tasks]. Wydawnictwo Uniwersytetu Ekonomicznego we Wrocławiu, Wrocław.

2. Gruszczyński, M., Podgórska, M. (2000). Ekonometria [Econometrics]. Warszawa: Oficyna Wydawnicza SGH, Warszawa.

3. Klepacki, B. (1984). Wybór próby w badaniach ekonomiczno-rolniczych [Selection of the sample in economic and agricultural research]. Wydawnictwo SGGW, Warszawa.

4. Madala, G. (2006). Ekonometria [Econometrics]. PWN, Warszawa.

5. Ramanathan, R. (1995). Ekonometria wprowadzająca $\mathrm{z}$ zastosowaniami [Introductory Econometrics with Applications]. Harcourt Brace College Publishers, San Diego.

6. Różyński, J. (2014). Oddziaływanie wielkości i struktury funduszy własnych na efektywność banków spółdzielczych [Influence of the size and structure of own funds on the effectiveness of cooperative banks]. Wydawnictwo Uniwersytet Szczeciński, Szczecin.

7. Szustak, G. (2009). Kapitał własny a bezpieczeństwo, efektywność i konkurencyjność banku [Equity and safety, efficiency and competitiveness of the bank]. Wydawnictwo Akademii Ekonomicznej, Katowice.

8. Welfe, A. (2003). Ekonometria [Econometrics]. PWN, Warszawa. 